\title{
Growth, Development, and Yield of Head Lettuce Cultivated on Paper and Polyethylene Mulch
}

\author{
D. Brault ${ }^{1}$ and K.A. Stewart ${ }^{2}$ \\ Department of Plant Science, Macdonald Campus of McGill University, Ste- \\ Anne-de-Bellevue, Québec, Canada, H9X 3V9

\section{S. Jenni ${ }^{3}$ \\ Horticultural Research and Development Centre, Agriculture and Agri-Food Canada, St-Jean-sur-Richelieu, Québec, Canada, J3B 3E6}

Additional index words. crisphead lettuce, organic soil, soil compaction, soil temperature, relative growth rate, Lactuca sativa

\begin{abstract}
Lettuce plants (Lactuca sativa L. cv. Ithaca) were transplanted into organic soil and onto beige paper, black paper, and coextruded white/black polyethylene mulches in 1997 and 1998. A weeded bare ground plot was also tested. Transplanting in 1997 occurred in July under warm and dry conditions. Plants grown on mulch established better when the mean air temperature during the week after transplanting was $22.5^{\circ} \mathrm{C}$. The mortality rates of the bare ground control were $30 \%$. All mulches significantly reduced plant mortality in 1997. In 1998, air temperature during the week after transplanting (June) was $14.6^{\circ} \mathrm{C}$. Plant mortality in 1998 was $1.3 \%$ for the control and $1.5 \%$ for the mulched plots. For both years, plants grown on mulched plots had higher relative growth rates than the control at the start of the season. Head fresh weight was 3.6 times (1997) and 1.2 times (1998) greater for lettuce grown on mulch compared with lettuce grown in a weeded control. Soil bulk density was lower under mulch than in the control plots in 1997.
\end{abstract}

Lettuce, an important crop in Quebec, was valued at 40 million dollars and accounts for $80 \%$ of the Canadian production (Statistiques agro-alimentaires, 1998). Two factors limiting the growth of head lettuce are poor plant establishment and weed competition. Traditionally, early crops of lettuce have been transplanted while midsummer crops were direct seeded. Transplanting has advantages over direct seeding. It increases crop uniformity, eliminates the need for thinning and reduces the growing period (Ryder, 1979). Plants are initially irrigated via sprinklers at planting and then depend on natural rainfall. Transplanting is practiced less during the summer as the hot and dry conditions often lead to transplant desiccation and death. However, direct seeded lettuce during this period may have erratic emergence and development and is subject to intense weed competition. Competition from weeds has been shown to reduce lettuce head

Received for publication 19 Oct. 2000. Accepted for publication 3 May 2001. Agr. and Agri-Food Can., Saint-Jean-sur-Richelieu (Quebec), Contribution no. $335 / 2001.04 .02 \mathrm{R}$. This paper is a portion of a MS thesis submitted by D. Brault. We thank the technicians for their assistance. Mention of trade name or specific equipment does not constitute a guarantee, warranty or endorsement of the product. This project was supported by a grant from the Matching Investment Initiative (MII) of Agriculture and Agri-Food Canada in collaboration with Cascades Multi-Pro Inc. and Innotag Inc. D. Brault was supported by a Fellowship from the Fonds pour la formation de Chercheurs et l'Aide à la Recherche.

${ }^{1}$ Graduate Student.

${ }^{2}$ Associate Professor

${ }^{3}$ Research Plant Physiologist. firmness (Shrefler et al., 1996) and marketable yields (Roberts et al., 1977). Mechanical or manual weeding can damage lettuce roots. Growing lettuce on mulch could provide a solution to these problems.

Mulch films have been reported to maintain soil moisture (Edmond, 1929; Knavel and Mohr, 1967; McCubbin and Westover, 1932), reduce soil compaction (Carolus and Downes, 1958; Ekern, 1967; Smith, 1931) and control weeds if opaque to photosynthetically active radiation (Emert, 1957; Smith, 1968). The most commonly used opaque mulch, black polyethylene, may not be the most appropriate for use in a cool season crop such as lettuce, because of its soil warming capacity. A coextruded white/black polyethylene may be better adapted to this crop since its upper surface reflects incoming light thereby reducing surface temperatures, and its black underside reduces weed growth (Carnell, 1996).

Paper mulches reportedly had problems of anchorage and longevity (Anderson et al., 1995; Flint, 1928; Hutchins, 1933). A paper mulch that could remain intact for the duration of a short season crop such as headed lettuce, reduce weed growth, and result in greater yield than the current method of bare ground production would be very useful. Paper mulch would also have the advantage of decomposing into the soil at the end of the growing season, contributing to a reduction in waste compared with the polyethylene mulch. The primary objective of this research was to characterize the effects of paper and polyethylene mulches on the growth and development of lettuce on organic soils.
Location.The experiment took place during the summers of 1997 and 1998 in a well decomposed organic soil (humisol). In 1997, the experiment was carried out in Sherrington,

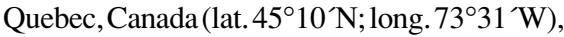
whereas the experiment 1998 was done on a neighboring field located in Napierville, Quebec, Canada (lat. $45^{\circ} 11^{\prime} \mathrm{N}$, long. $73^{\circ} 25^{\prime} \mathrm{W}$ ). The experimental plots were adjacent to commercial lettuce fields with a soil pH of 5.7 in 1997 and 4.8 in 1998. No preemergence herbicide was applied and the field was fertilized as recommended (CPVQ, 1996).

Experimental layout. Paper mulch treatments consisted of a kraft paper $\left(83 \mathrm{~g} \cdot \mathrm{m}^{-2}\right.$; Cascades Multi-Pro, Drummondville, Que.) with various coatings. In 1997, both a beigeand a black-colored paper were coated with latex on both sides. Since the latex-coated paper rapidly degraded, a new series of three papers was tried in 1998. One paper was coated with a biodegradable polymer on the underside, another had the polymer coated on the top side and the third was coated with the polymer on both sides. In both years, paper mulch treatments were compared with a weeded control and a white/black coextruded polyethylene mulch (0.028 mm; Plastitech Culture, St-Rémi, Que.). Treatments were replicated four times in a randomized complete-block design. Plots consisted of 0.15-m-high and 0.76-m-wide raised beds that were $10.26 \mathrm{~m}$ long in 1997 and $12 \mathrm{~m}$ long in 1998. Beds and blocks were spaced 1.27 and $1 \mathrm{~m}$ apart, respectively. Mulches were laid manually onto wet soil on 9 July and 3 June in 1997 and 1998, respectively. Planting holes of $3.2 \mathrm{~cm}$ in diameter were made in each mulch.

Lettuce seedlings cv. Ithaca were 29 and 25 days old in 1997 and 1998, respectively, when transplanted into the field a day after the mulch was laid. Fresh weights of seedlings were measured. Before transplanting, seedlings were fertilized with 10-31-4+0.003\% IBA (Les Services N-P-K, Varennes, Que.) at the rate of $10 \mathrm{~mL} \cdot \mathrm{L}^{-1}$ of water. Plants were staggered in adjacent rows with $35.6 \mathrm{~cm}$ within and $44.5 \mathrm{~cm}$ between rows. Each plant was individually watered by pouring $250 \mathrm{~mL}$ of water by hand directly in the planting hole at transplanting. An additional $150 \mathrm{~mL}$ of water per plant was applied by hand on 6 June in 1998 because the sprinkler irrigation was not installed at that time. The sprinkler irrigation system (Dubois et fils, StRémi, Que., $59 \mathrm{~L} \cdot \mathrm{min}^{-1}$ ) was installed immediately after (1997) and five days after transplanting (1998) and was active for $\approx 1 \mathrm{~h} / \mathrm{d}$ for the first $4 \mathrm{~d}$ (1997) and $2 \mathrm{~d}$ (1998) after installation. No irrigation was applied later in the season.

Soil bulk density measurements. Soil bulk density was measured weekly with a core sampler to a depth of 9-10 cm. Soil samples were taken within a randomly assigned $25 \times 25-\mathrm{cm}$ area within each plot between four lettuce plants. A plastic bag filled with soil was put over the sampled area to avoid wind damage to the mulch. Sampling area for soil bulk density measurements was $5.7 \mathrm{~m}$ away from soil thermocouples. 
Microclimate measurements. Air and soil temperatures were measured using copperconstantan thermocouples connected to an AM416 multiplexer and a CR-10 datalogger (Campbell Scientific Canada, Edmonton, Alta.). Air temperature in the field was measured using thermocouples inside 15 -cm-long white-painted tubes with a diameter of $3.3 \mathrm{~cm}$, installed $10 \mathrm{~cm}$ above the bare soil surface at two locations. Two soil thermocouples in 1997 and three in 1998 were placed perpendicularly and $28 \mathrm{~cm}$ from the right edge of each treatment in one block, $10 \mathrm{~cm}$ deep, between two lettuce plants. Air and soil temperature readings taken at 10min intervals were averaged over each hour.

Lettuce growth and development measurements. Ten plants per treatment per block were harvested when more than $80 \%$ of the lettuces in at least one treatment had 10 leaves $>2 \mathrm{~cm}$ in length(10-leaf stage). The leaves were counted, and fresh weight of the plants were recorded and used to calculate the relative growth rate. Twenty plants per treatment per block were harvested when $>80 \%$ of the lettuce heads in at least one treatment had reached acceptable firmness and weight for the market. Leaves around the lettuce head (wrapper leaves) were removed, counted and weighed. The fresh weight of the heads was recorded. The heads were halved and the length of the stems was measured.

Statistical analysis. Data were analyzed using the Statistical Analysis System (SAS Institute, 1998). When the numbers of observations were unequal at final harvest due to plant mortality, the variance and the mean for each treatment per block were initially obtained by an univariate analysis. A general linear model was then fitted to the treatment means per block. The treatment main effects were estimated by weighted least squares using the variances of the treatment means per block as weights. The data was subjected to a square root transformation when necessary in order to satisfy homogeneity of variance and normality. When treatment effects were significant $(P<$ $0.05)$, differences among means were detected using orthogonal contrasts.

\section{Results and Discussion}

Microclimate. The experiment was conducted from 9 July until 21 Aug. and from 3 June until 15 July, in 1997 and 1998, respectively. Plants were transplanted under midsummer conditions in 1997 and under spring conditions in 1998. The mean air temperature in the field for the week after transplantation was $22.5^{\circ} \mathrm{C}$ and $14.6^{\circ} \mathrm{C}$ in 1997 and 1998 , respectively. The mean air temperature from transplanting until the 10 -leaf stage was $20.2^{\circ} \mathrm{C}$ in 1997 and $18.6^{\circ} \mathrm{C}$ in 1998 . Head lettuce has been reported to grow best between $15^{\circ} \mathrm{C}$ and $18^{\circ} \mathrm{C}$ (Lorenz and Maynard, 1988). The average minimum air temperature was $11.9^{\circ} \mathrm{C}$ and $13.7^{\circ} \mathrm{C}$ and the average maximum air temperature $28.2^{\circ} \mathrm{C}$, and $26.2^{\circ} \mathrm{C}$ in 1997 and 1998 , respectively.

Soil temperature has been found to be more closely correlated to lettuce growth rate than air temperature (Scaife, 1973; Wurr et al., 1981). The soil temperature of the weeded control was higher in 1997 than in 1998. The mean soil temperature $5 \mathrm{~d}$ after planting until harvest was $20.3^{\circ} \mathrm{C}$ in 1997 and $18.5^{\circ} \mathrm{C}$ in 1998 . In 1997 , the highest average mean soil temperature $\left(22.5^{\circ} \mathrm{C}\right)$ was found under the black paper mulch coated with latex. The soil temperature under the white/black polyethylene mulch was in average $21^{\circ} \mathrm{C}$. In 1998 , soil temperature readings were incomplete for two treatments at the beginning of the season making difficult the comparison of mean soil temperatures among mulch treatments throughout the crop season. However, the mean soil temperature during the period from the 10-leaf stage until harvest in 1998 was $19.6^{\circ} \mathrm{C}$ for beige paper mulches, $18.6^{\circ} \mathrm{C}$ for black paper mulch and $19.4{ }^{\circ} \mathrm{C}$ for white/ black polyethylene mulch. Soil temperature under the black mulch should be consistently higher than that of the coextruded white/ black mulch since white mulch reflects more light (Decoteau et al., 1986). However, the covering of the mulch by lettuce leaves near the end of the experiment may have reduced this influence on soil temperatures after the 10-leaf stage in 1998.

After establishment, the lettuce plants were not irrigated and depended on natural rainfall. Precipitation in 1997 (96 mm) was less than half compared to 1998 (204 mm). For both years, rainfall was lower during the first $21 \mathrm{~d}$ (40 $\mathrm{mm}$ in 1997 and $76 \mathrm{~mm}$ in 1998) compared with the last $21 \mathrm{~d}$ of the experiment $(56 \mathrm{~mm}$ in 1997 and $128 \mathrm{~mm}$ in 1998). The growing season of 1998 was characterized by periods of heavy rain, particularly at the end of June and early July. A localized hailstorm that damaged the wrapper leaves of the plants occurred on 10 July 1998 (37 d after planting).

Soil compaction may cause variability in lettuce growth as it was found to decrease the number of roots and the water flux to the root system (Jones and Tardieu, 1998). In organic soil more specifically, crusting of the soil surface may occur and may cause problem in plant establishment, particularly in the spring. In
1997, soil bulk density was more stable and slightly lower in mulched treatments compared with the control (Table 1). Soil bulk density increased over time for the weeded control particularly between 21 and $28 \mathrm{~d}$ after mulch placement. The soil bulk density was twice less in the 1998 site than in the 1997 site. Soil compaction during that year was minimal and there was no significant difference among the treatments.

Growth and development of lettuce. In 1997 and in 1998, the use of a mulch increased the relative growth rates (RGR) of lettuce in early (transplant to 10-leaf stage) rather than later development (10-leaf stage to harvest; Table 2). High temperatures and low rainfall, particularly at the start of the 1997 season may have delayed the establishment and growth of the control plants.

In 1997, more plants died in the control plots compared with those in mulched plots (Table 2 ). The high rate of mortality for plants grown on the beige mulch $(15 \%)$ was due in part to the dry, hot conditions, and because some plants were trapped under the mulch which may have been avoided with a mechanical laying of mulches. The lower mortality levels in 1998 compared with those of 1997 reflect better environmental conditions at planting time.

In $1997,<50 \%$ of the plants in the weeded control produced heads at harvest (Table 2). Although the new leaves started to cup later in the season, most of the plants had no visible head at harvest. Plants in the mulched treatments produced significantly more heads than plants in the weeded control. In 1998, over $90 \%$ of the experimental lettuce plants, including control, produced heads.

In 1997, lettuce plants (head + wrapper leaves) grown on paper and polyethylene mulches were 2.7 times heavier than those grown in the control plot (Table 3). The lack of mulch during hot and dry temperatures negatively affected the growth of the lettuce plants in the weeded control in 1997. Plants grown on mulches had significantly fewer wrapper leaves

Table 1. Effect of mulch on soil bulk density $\left(\mathrm{g} \cdot \mathrm{cm}^{-3}\right)$ for each treatment $7,14,21,28$, and $35 \mathrm{~d}$ after mulch placement onto an organic soil.

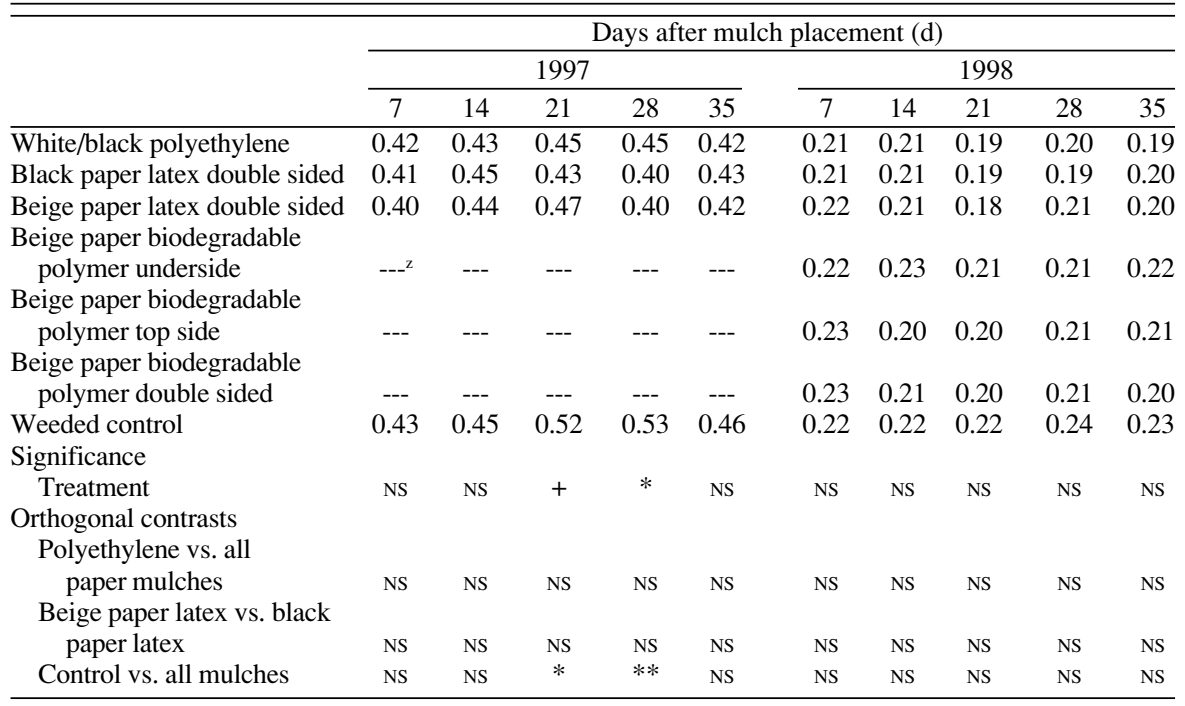

${ }^{2}$ These mulches were not used in 1997.

Ns, $,+, * * *, * * *$ Nonsignificant or significant at $P \leq 0.10,0.05,0.01$, or 0.001 , respectively. 
Table 2. Effect of mulch type on relative growth rate (RGR, fresh weight basis) of lettuce, on percent mortality and on percentage of headed plants at harvest in 1997 and 1998. Lettuce was transplanted in organic soil on 10 July 1997 and 4 June 1998 and then harvested on 20 Aug. and 14 July, respectively.

\begin{tabular}{|c|c|c|c|c|c|c|c|c|}
\hline \multirow[b]{3}{*}{ Mulches } & \multicolumn{4}{|c|}{$\operatorname{RGR}\left(\mathrm{g} \cdot \mathrm{g}^{-1} \cdot \mathrm{d}^{-1}\right)$} & & & & \\
\hline & \multicolumn{2}{|c|}{$\begin{array}{c}\text { Planting to } \\
10 \text { leaves }\end{array}$} & \multicolumn{2}{|c|}{$\begin{array}{l}10 \text { leaves } \\
\text { to harvest }\end{array}$} & \multicolumn{2}{|c|}{$\begin{array}{l}\text { Mortality }^{\mathrm{z}} \\
(\%)\end{array}$} & \multicolumn{2}{|c|}{$\begin{array}{c}\text { Headed plants }{ }^{y} \\
(\%)\end{array}$} \\
\hline & $\overline{1997}$ & 1998 & 1997 & 1998 & 1997 & 1998 & 1997 & 1998 \\
\hline White/black polyethylene & 1.35 & 2.50 & 0.91 & 0.71 & 5.00 & 1.25 & 91.25 & 93.75 \\
\hline Black paper latex double sided & 1.42 & 2.86 & 0.79 & 0.74 & 2.50 & 1.25 & 93.75 & 98.75 \\
\hline Beige paper latex double sided & 1.38 & 2.15 & 0.89 & 0.86 & 15.00 & 3.75 & 85.00 & 95.00 \\
\hline $\begin{array}{l}\text { Beige paper biodegradable } \\
\text { polymer underside }\end{array}$ & $--^{x}$ & 3.27 & --- & 0.71 & --- & 2.50 & --- & 95.00 \\
\hline $\begin{array}{l}\text { Beige paper biodegradable } \\
\text { polymer top side }\end{array}$ & -- & 2.89 & --- & 0.66 & --- & 0.00 & -- & 100.00 \\
\hline $\begin{array}{l}\text { Beige paper biodegradable } \\
\text { polymer double sided }\end{array}$ & --- & 2.95 & --- & 0.65 & --- & 0.00 & --- & 98.75 \\
\hline Weeded control & 0.92 & 2.04 & 0.68 & 0.87 & 30.00 & 1.25 & 46.25 & 92.50 \\
\hline $\begin{array}{r}\text { Significance } \\
\text { Treatment }\end{array}$ & $* *$ & * & NS & NS & * & NS & $* *$ & NS \\
\hline $\begin{array}{l}\text { Orthogonal contrasts } \\
\text { Polyethylene vs. all } \\
\text { paper mulches }\end{array}$ & NS & NS & NS & NS & NS & No & NS & NS \\
\hline $\begin{array}{l}\text { Beige paper latex vs. } \\
\text { black paper latex } \\
\text { Control vs. all mulches }\end{array}$ & $\begin{array}{c}\text { NS } \\
* * *\end{array}$ & $\begin{array}{l}+ \\
*\end{array}$ & $\begin{array}{l}\text { NS } \\
\text { NS }\end{array}$ & $\begin{array}{l}\text { NS } \\
\text { NS }\end{array}$ & $\begin{array}{l}+ \\
* *\end{array}$ & $\begin{array}{l}\text { NS } \\
\text { NS }\end{array}$ & $\begin{array}{c}\text { NS } \\
* * *\end{array}$ & $\begin{array}{l}\text { NS } \\
\text { NS }\end{array}$ \\
\hline
\end{tabular}

${ }^{2}$ Percentage data were arcsin transformed before analysis.

yPercentage of headed plants for all initially transplanted lettuce.

${ }^{x}$ These mulches were not used in 1997.

Ns, $+, *, * * * * * *$ Nonsignificant or significant at $P \leq 0.10,0.05,0.01$, or 0.001 , respectively.

Table 3. Effect of mulch type on lettuce plant weight, number of wrapper leaves, head weight and stem length in 1997 and 1998. Lettuce was transplanted in organic soil on 10 July 1997 and 4 June 1998 and then harvested on 20 Aug. and 14 July, respectively.

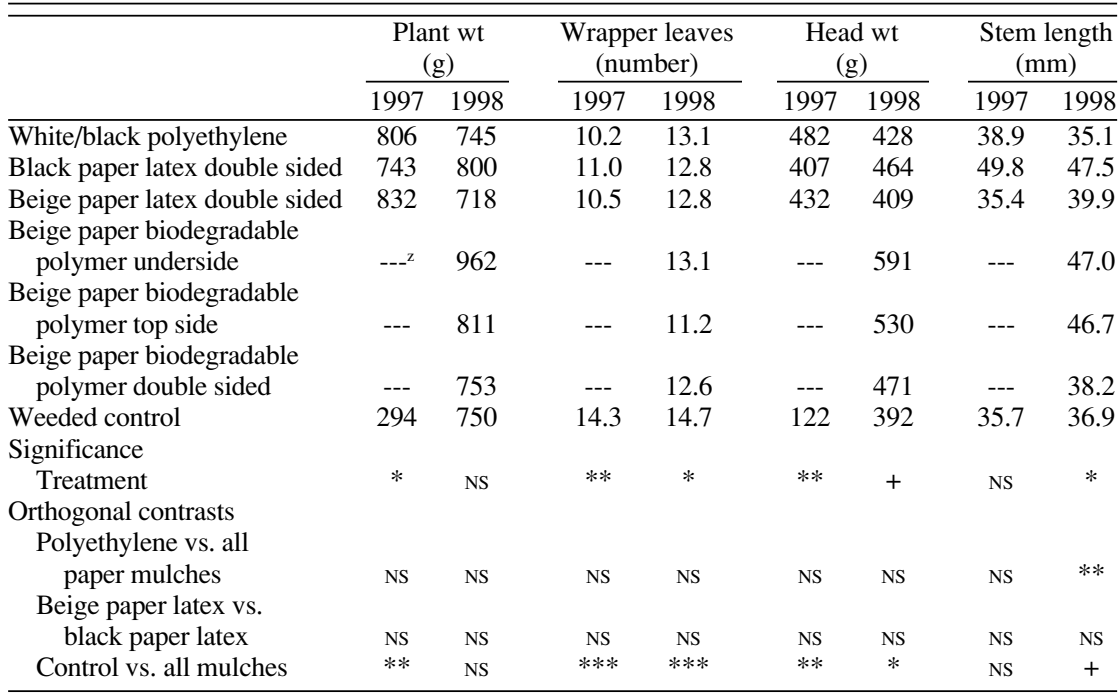

${ }^{2}$ These mulches were not used in 1997.

Ns, $+, *, * *, * * *$ Nonsignificant or significant at $P \leq 0.10,0.05,0.01$, or 0.001 , respectively.

compared with plants in the control plots for both years (Table 3). Leaves started to cup faster with plants grown on mulches compared with the control.

In 1997 and 1998, head weight of the control plants was significantly lower in the weeded plots compared with mulched treatments (Table 3). Stem length were similar for all treatments in 1997 but had a tendency to be shorter when lettuces were grown on the polyethylene and the control compared with the paper mulches in 1998.

Both the paper and polyethylene mulch promoted growth and development of head lettuce as reflected by earlier heading and heavier heads compared with a manually weeded con-

\section{Literature Cited}

Anderson, D.F., M.A. Garisto, J.C. Bourrut, M.W Schonbeck, R. Jaye, A. Wurzberger, and R. DeGregorio. 1995. Evaluation of paper mulch made from recycled materials as an alternative to plastic film mulch for vegetables. J. Sustainable Agr. 7:39-61

Carnell, C.D. 1996. Film de paillage blanc hautement réflectif/noir sous climat chaud. (High reflective white on black mulch plastics in hot climates). Plasticulture 111:17-22.

Carolus, R.L. and J.D. Downes. 1958. Studies on muskmelon and tomato responses to polyethylene mulching. Michigan Agr. Expt. Sta. Quart. Bul. 40:770-785.

CPVQ.Conseil des Productions Végétales du Québec. 1996. Grille de référence en fertilisation. 2 ième édition. AGDEX 540.

Decoteau, D.R., D.D. Daniels, M.J. Kasperbauer, and P.G. Hunt. 1986. Colored plastic mulches and tomato morphogenesis. Proc. Natl. Agr. Plastic Congress. 19:240-248.

Edmond,F.B. 1929. Mulch paper for vegetable crops. Michigan Agr. Expt. Sta. Quart. Bul. 2:115-117

Ekern, P.C. 1967. Soil moisture and soil temperature changes with the use of black vapor barrier mulch and their influence on pineapple. Soil Sci. Soc. Amer. Proc. 31:270-275.

Emert, E.M. 1957. Black polyethylene for mulching vegetables. Proc. Amer. Soc. Hort. Sci. 69:464 469.

Flint, L.H. 1928. Crop-plant stimulation with paper mulch. Technical Bul., U.S. Dept. Agr., Washington, D.C. 75:1-20.

Harris, R.E. 1965. Polyethylene covers and mulches for corn and bean production in northern regions. Proc. Amer. Soc. Hort. Sci. 87:288-294.

Hutchins, A.E. 1933. Mulch paper in vegetable production. Minnesota Agr. Dept. Sta. Bul. 298:1-18

Jones, H.G. and F. Tardieu. 1998. Modeling water relations of horticultural crops: A review. Scientia Hort. 74:21-46.

Knavel, D.E. and Mohr, H.C. 1967. Distribution of roots of four different vegetables under paper and polyethylene mulches. Proc. Amer. Soc. Hort. Sci. 91:589-597.

Lorenz, O.A. and D.N. Maynard. 1988. Knott's Handbook for Vegetable Growers. 3rd ed. Wiley, New York.

McCubbin, R.N. and K.C. Westover. 1932. The influence of soil type on results from paper mulch trials with tomatoes. Proc. Amer. Soc. Hort. Sci. 29:458-462.

Ryder,E.J. 1979.Leafy salad vegetables. 1sted. AVI, Westport, Conn.

Roberts, H.A., R.T. Hewson, and M.E. Ricketts. 1977. Weed competition in drilled summer lettuce. Hort. Res. 17:39-45.

Scaife, M.A. 1973. The early growth of six lettuce cultivars as affected by temperature. Ann. Appl. Biol. 74:119-128.

Shrefler, J.W., W.M. Stall, and J.A. Dusky. 1996. Spiny amaranth (Amaranthus spinosus L.), a serious competitor to crisphead lettuce (Lactuca sativa $\mathrm{L}$.). HortScience 31:347-348.

Smith, A. 1931. Effect of paper mulches on soil temperature, soil moisture, and yields of certain crops. Hilgardia. 6:159-201.

Smith, D.F. 1968. Mulching systems and techniques. Proc. Natl. Agr. Plast. Conf., 8:112-118

Statistiques agro-alimentaires. 1998. Bureau de la Statistique du Québec. 2 ième semestre. Quebec.

Wurr, D.C.E., J.R. Fellows, and G.E.L. Morris. 1981. Studies of the hearting of butterhead lettuce: Temperature effects. J. Hort. Sci. 56:211-218. 